\title{
Religious Education \\ in Public Secondary Schools: \\ Theory, Methodology \\ AND PRAXIS*
}

Vitaliy PROSHAK, MDiv, MTh, MA

E-mail: vitaliy.proshak@gmail.com

\begin{abstract}
Religion, also in its educational dimension, is an essential component of contemporary society. The present article Religious Education in Public Secondary Schools: Theory, Methodology and Praxis is an attempt to define religious education in public secondary school context in connection to its theory, methodology and praxis. An overview of the existing theories and methods of religious education is presented in the article on the base of the research works of Jeff Astley, Cok Bakker, Thomas H. Groom,
\end{abstract}

\begin{abstract}
Robert Jackson, Siebren Miedema, Gabriel Moran, John Sealey and others. The final part of the article introduces reader to a variety of praxis of religious education in Europe as described by Jean-Paul Willaime and Vitaliy V. Proshak. Analyzing European praxis in relation to religious education, author concludes that treatment of religious education by state could testify about democracy development of the state itself.
\end{abstract}

Keywords: religion, education, school, confession, state.

\footnotetext{
* The article received on 21.12.2017; approved for publication on 18.03.2018.
}

In this article author uses the term 'religious education' in its inclusive definition that could be applicable to all confessional/ religious dimensions of education. The focus of the article is not on the religious/ confessional character or differences in education, but on the general theory, methodology and praxis in relation to religion and education in the context of secondary school. 


\section{Introduction}

Approaching the task to describe religious education and its theory, methodology and praxis, it would be quite helpful to turn to a short description of an act of education itself. In relation to this question, Thomas Groom mentions that "it is difficult to name what is actually done in the act of educating." ${ }^{1}$ In spite of the fact that education has been an essential dynamic component of the human intellectual development and "is as old as human consciousness", it still remains a mystery act. ${ }^{2}$ The English word education/ educate comes from Latin duco/ducare/ ducere and actually implies the process of movement "leading out". ${ }^{3}$ Every process of leading out has connection to 1) the starting point, 2) the movement itself, and 3) the point of arrival. The present article Religious Education in Public Secondary Schools: Theory, Methodology and Praxis is an attempt to define this process of leading out in connection to religious education.

The history of Christianity mentions Tertullian, who once asked the question related to the connection, if any, between the Academy and the Church: "What has Athens to do with Jerusalem? What agreement is there between the Academy and the Church?"4 The philosophical background for the question was the relation between the pursuit of worldly knowledge and faith in the revelation of God. ${ }^{5}$ In other words, Tertullian was asking about the input of different philosophical positions into the spread of religious beliefs through an application of educational theory. The later development of this discussion led to a division in opinions among the philosophers of education and religion. Opinions vary based on the religious claims of a particular philosopher. Some of the thinkers have declared that there is "an important and intimate relationship between the life of the intellect and the life of faith." ${ }^{6}$ As Thomas Groom states "...if needed all education is ultimately a reaching for transcendence and an expression of that human quest, then all good education can be called religious." ${ }^{7}$ However, educators in, for example, mathematics or chemistry would hardly agree that they perform a religious act; even in spite of the fact that well known scientists Isaac Newton $\left(1642\right.$ - 1727) called himself a theologian and not a scientist. ${ }^{8}$ From the other side, the opposite group of philosophers argues that even the term Religious

\footnotetext{
${ }^{1}$ Thomas H. Groom, Christian Religious Education: Sharing Our Story and Vision (New York, NY; HarperSanFrancisco, 1981), 3.

${ }^{2}$ Groom, 1981, 5.

${ }^{3}$ Charlton T. Lewis, ed., An Elementary Latin Dictionary, "Duco” (Oxford; Oxford University Press, 1989 [1891]), 263; Thomas H. Groom, 1981, 5.

${ }^{4}$ Raymond Abba, "Athens and Jerusalem: Religious Studies in the Secular University," an open lecture at California State University, Fullerton, California, May 8, 1974, published in Religious Education, 70:4 (1975, July/ August), 355.

${ }^{5}$ Vitaliy V. Proshak, A Philosophy of Religious Education in an Pluralist Society: Christian Evangelical Education in Ukraine Since 1991, MET thesis, Tyndale Theological Seminary, the Netherlands, February $2007,23$.

${ }^{6}$ Peterson, Michael L. "Philosophy of Education: Issues and Options," in Contours of Christian Philosophy, Stephen C. Evans, ed. (Downers Grove, Illinois; InterVarsity Press, 1986), 80.

${ }^{7}$ Groom, 1981, 21.

${ }^{8}$ R.P.H. Munnik, course notes/ discussions, Course U 40063 Christianity in Dialogue with the Modern Arts, Semester II, 2010 - 2011, Tilburg School of Theology, Tilburg University.
} 
Education is not comprehensible and has a contradiction in itself. ${ }^{9}$ This group of experts argues that religious education should not be religious in its character and has to be done in a neutral and objective way. ${ }^{10}$

The following below sections on definition and classification of religious education presents the reader with a glimpse on a deeper discussion on this topic.

\section{Religious Education Defined}

Approaching the task to define what is religious education, it should be made clear that "religious education is a rich term." 11 There is a multiple variety of definitions and viewpoints on religious education: this term includes academic teacher training and various philosophical and practical aspects of teaching methods and approaches to religious and value education at school. ${ }^{12}$ For the purpose of this article the following definitions should be considered. Charles F. Melchert says that religious education is of practical help in the explanation of theoretical religious phenomenon. He gives the following definition of religious education: "Religious Education is the sacred process of helping others to understand religious claims and traditions which is done in the ways appropriate to religion." ${ }^{13}$ In relation to this, Jim Wilhout in his book Christian Education: The Search for Meaning says that Christian religious education is "dedicated to helping people discover God's meaning for life." ${ }^{14}$ Thomas H. Groom, supporting the aforementioned definitions, continues the dialogue by mentioning that "religious education activity is a deliberate attending to the transcendent dimension of life by which a conscious relationship to an ultimate ground of being is promised and enabled to come to expression." ${ }^{15}$ On the base of this, as Thomas H. Groom states, religious education should empower people on their quest for the transcendent and ultimate ground of being. ${ }^{16}$ However, the group of thinkers that holds to the theory of religious neutrality of religious education communicates that in light of the contemporary demand for increasing tolerance for the purpose of "living together as equals in dignity" the aim of religious education should not be to indoctrinate students into any one particular form of religious philosophy or into the basic acceptance of religion as opposition to

\footnotetext{
${ }_{9}^{9}$ Jeff Astley, The Philosophy of Christian Religious Education (Birmingham, Alabama; Religious Education Press, 1994), 41.

${ }^{10}$ Gabriel Moran, "Religious Education and International Understanding," in Education, Religion, and Society: Essays in Honour of John M. Hull, Dennis Bates, Gloria Durka, and Friederich Schweitzer, eds., Series Routledge Research in Education (London and New York; Routledge, Taylor \& Francis Group, 2006), 42.

${ }^{11}$ Groom, 1981, 22.

${ }^{12}$ Wolfram Weisse, "Analysis of the Teacher's Responses to Religious Diversity in the Course of the REDCo Project - A Foreword," in Teachers Responding to Religious Diversity in Europe, Anna van der Want, Cok Bakker, Ina ter Avest, Judith Everington, eds., Vol. 8, Series Religious Diversity and Education in Europe (Münster, Waxmann, 2009), 9.

${ }^{13}$ Charles Melchert, "What is Religious Education?" in Critical Perspectives on Christian Education, Jeff Astley and Leslie J. Francis, eds. (Melksham, Wiltshire: The Cromwell Press, 1994), 59.

${ }^{14}$ Jim Wilhout, Christian Education: The Search for Meaning, 2 ed. (Grand Rapids, Michigan: Baker Book House, 1991), 11.

${ }^{15}$ Groom, 1981, 22.

${ }^{16}$ Groom, 1981, 22.
} 
naturalistic faith. ${ }^{17}$ As Moran continues, the religiously neutral character of religious education does not exactly mean that pupils should not be introduced to the richness of different religious traditions; religious education should still treat each religious movement in particular and not all religious traditions in common. ${ }^{18}$ Therefore, in spite of the neutral character of religious education, religious diversity dialogue should be included as part of the teaching process since it can generate understanding of the other religious tradition, create openness in opinion-exchange on religious and value differences, and, might possibly lead to the appreciation of plurality. ${ }^{19}$

Diagram 1: Threefold Diversity Dialogue in Religious Education

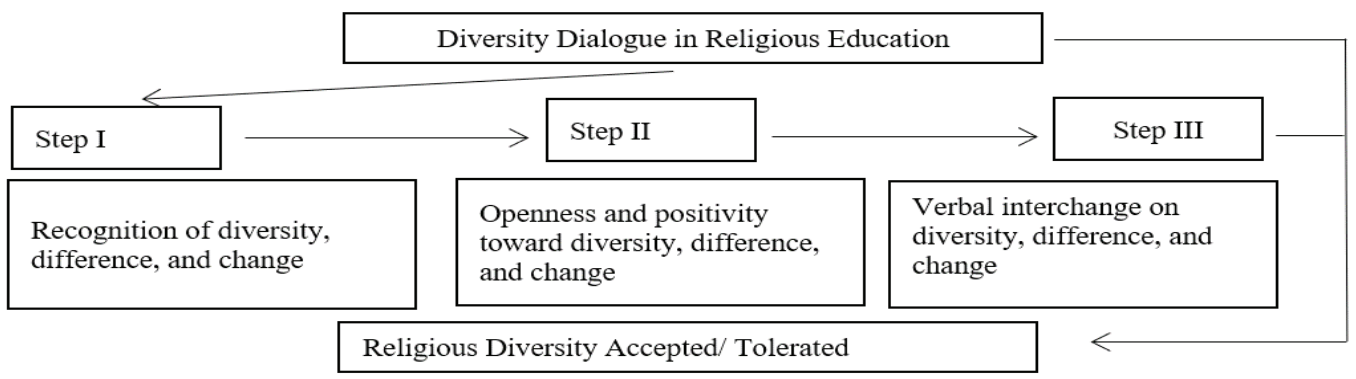

Schema modified and adapted from Robert Jackson, Intercultural Education and Religious Education, 2006, 56.

In respond to the demand on interreligious dialogue in religious education, the group of researchers from Warwick Religion and Education Research Unit (WRERU), Warwick University, under the leadership of Robert Jackson developed an interpretive approach to religious education. The aim of the interpretive approach, as Robert Jackson states, is "to help children and young people to find their own positions within the key debates about religious plurality." ${ }^{20}$ While presenting the variety of religious faith-claims, interpretive approach safeguards the personal choice of pupils to connect the presented truth to the personal experience.

\footnotetext{
${ }^{17}$ John Hick, "The Contribution of the Philosophy of Religion to Religious Education," in Education, Religion, and Society: Essays in Honour of John M. Hull, Dennis Bates, Gloria Durka, and Friederich Schweitzer, eds., Series Routledge Research in Education (London and New York; Routledge, Taylor \& Francis Group, 2006), 62.

${ }^{18}$ Gabriel Moran, Religious Education and International Understanding, 2006, 42.

${ }^{19}$ Ina ter Avest, Cok Bakker, and Anna van der Want, "International Comparison - Commonalities and Differences of 36 Teachers Teaching Religion(s) in Europe", in Teachers Responding to Religious Diversity in Europe, Anna van der Want, Cok Bakker, Ina ter Avest, Judith Everington, eds., Vol. 8, Series Religious Diversity and Education in Europe (Münster, Waxmann, 2009), 121.

${ }^{20}$ Robert Jackson, Intercultural Education and Religious Education, 2006, 55.
} 
Diagram 2: Interpretive Approach to Religious Education

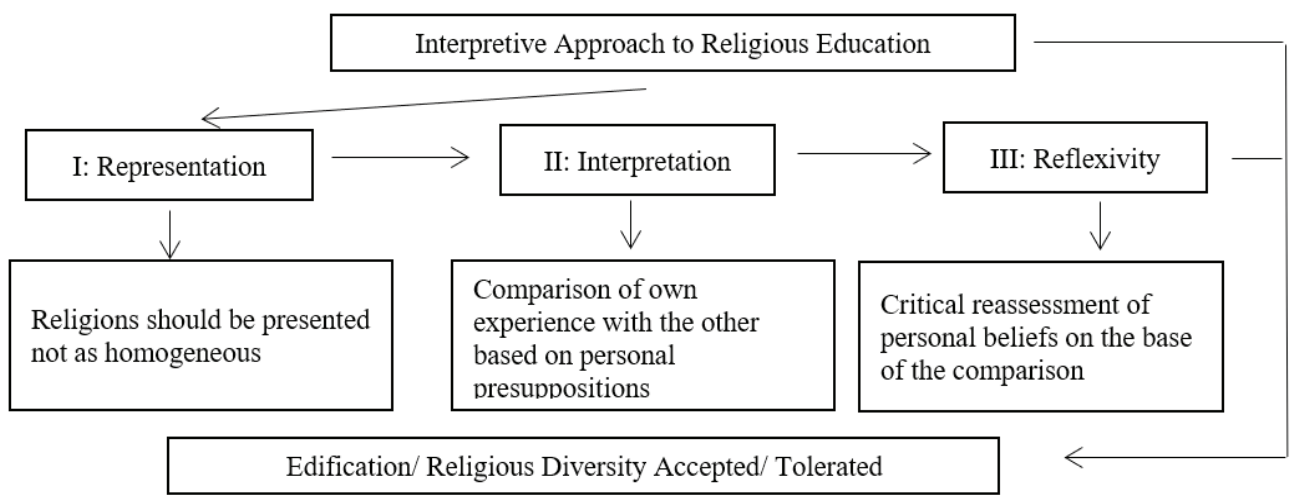

Schema modified and adapted from Robert Jackson, Understanding Religious Diversity in a Plural World: The Interpretive Approach, in "International Handbook of the Religious, Moral and Spiritual Dimensions in Education", Marain de Souza, Kathleen Engebretson, Gloria Durka, Robert Jackson, Andrew McGrady, eds., Series International Handbooks of Religion and Education, Vol. 1 (Dordrecht, The Netherlands; Springer, 2006), 400- 404.

\section{Classification of Religious Education}

The phenomena of religious education, in spite of its complexity, can be classified into two major categories. The first category of religious education emphasizes the nature of religion in application with educational practice; the second category concerns with function of religion in education. ${ }^{21}$

Table 3: Two Categories of Religious Education

\begin{tabular}{|l|l|l|}
\hline \multicolumn{1}{|c|}{$\begin{array}{c}\text { Category } \\
\text { Named }\end{array}$} & \multicolumn{1}{|c|}{ Category Described } & \multicolumn{1}{c|}{ Category Applied } \\
\hline $\begin{array}{l}\text { Nature of } \\
\text { Religion in } \\
\text { Education }\end{array}$ & $\begin{array}{l}\text { Concerns with explanation of the es- } \\
\text { sence of religion for education - how } \\
\text { can religion be described and adjusted } \\
\text { for educational theory; adaptation of re- } \\
\text { ligious beliefs for educational application }\end{array}$ & $\begin{array}{l}\text { Phenomenological ap- } \\
\text { proach to education; } \\
\text { moral approach to educa- } \\
\text { tion; spiritual approach to } \\
\text { education. }\end{array}$ \\
\hline $\begin{array}{l}\text { Function of } \\
\text { Religion in } \\
\text { Education }\end{array}$ & $\begin{array}{l}\text { Concerns with explanation of the role of } \\
\text { religion in education - what religion can } \\
\text { add to or how it can be used in educa- } \\
\text { tion; application of educational theory to } \\
\text { the essence of religion }\end{array}$ & $\begin{array}{l}\text { Confessional religious } \\
\text { education; neo-confes- } \\
\text { sional religious education; } \\
\text { hidden-confessional reli- } \\
\text { gious education; implicit } \\
\text { religious education }\end{array}$ \\
\hline
\end{tabular}

Table is adapted and modified from John Sealey, Religious Education: Philosophical Perspectives (London, UK: George Allen and Unwin Ltd., 1985), 31-60. ${ }^{21}$ John Sealey, Religious Education: Philosophical Perspectives (London, UK: George Allen and Unwin Ltd.,
1985), 31. 
The first category, which is concerned with nature of religion in education, sets out to study questions of spiritual, moral, and phenomenological approaches in religious education. The explanation of the first sort of religious education concerning the relationship of religious education to spiritual and moral education will be presented in the following table below with the similar title. The phenomenological approach to the nature of religion in education is based on the six dimensions of religion presented by Ninian Smart. ${ }^{22}$ The main characteristic of this style is to draw attention away from the confessional and dogmatic way of teaching religion to the rather objective manner, focusing on the different phenomena of religious experience..$^{23}$ In this manner, religious education should offer an impartial overview of different religious beliefs and practices equally placing them on the "map". Dutch law on education offers a clear example of the application of this approach to the situation of multicultural education in the country. ${ }^{24}$ The educational theory under this approach treats religion with respect to its beliefs and practices while encouraging interreligious debates. ${ }^{25}$ According to Robert Jackson, "phenomenological approach to religious education does not seek to promote any religious viewpoint, but recognizes the importance of informing about religious viewpoint" ${ }^{26}$

In contrast to the phenomenological approach to religious education, confessional religious education, which is one of the models of the theory of religious education that deals with function of religion in education, offers completely different methodology.

Confessional religious education aims on teaching for strengthening of the faith of the learners that should become apparent in their daily life. ${ }^{27}$ Such an educational approach is almost equal to devotional teaching or preaching in religious settings. The curriculum of religious education with this approach extends the activity of religious movement beyond its borders and brings it to the educational settings. It offers knowledge that is taught to be important for applying in the personal life and passing on to the next generation.

Neo-confessional religious education is a more liberal form of confessional religious education; it has the same purpose, only a slightly different form..$^{28}$ It is twofold in its methodology:

- pays attention to mental and emotional ability of pupils to understand religion for the purpose of accepting it;

\footnotetext{
${ }^{22}$ Ninian Smart, "Religion," in A New Dictionary of Christian Theology, Alan Richardson and John Bowden, eds. (London, Great Britain: SCM Press LTD, 1983), 496-497.

${ }^{23}$ John Sealey, Religious Education: Philosophical Perspectives, 1985, 33.

${ }^{24}$ Cok Bakker and Karin Griffioen, Introduction to the Religious Dimensions in Intercultural Education, 2001, 9; Ina ter Avest, "Conflict Matters: 'The Making of' a Difference", in Education in Conflict, Ina ter Avest, ed., Vol. 9, Series Religious Diversity and Education in Conflict (Münster, Waxmann, 2009), 16.

${ }^{25}$ Stephen Bigger, "Religious Education, Spirituality, and Anti-Racism," in Education, Culture, and Value, vol. V, Spiritual and Religious Education, Mal Leicester, Celia Modgil, and Sohan Modgil, eds. (London and New York: Falmer Press, 2000), 17-18.

${ }^{26}$ Robert Jackson, Religious Education: An Interpretive Approach, $5^{\text {th }}$ reprint (Great Britain, London: Hodder and Stoughton Education, 2003 [1997]), 8.

${ }^{27}$ John Sealey, Religious Education: Philosophical Perspectives, 1985, 43 and 44.

${ }^{28}$ Sealey, 1985, 43 and 45-47.
} 
- offers interreligious debate, but only for the purpose of showing tolerance to other religious movements. ${ }^{29}$

Hidden-confessional religious education seems to offer a choice of religions to pupils. ${ }^{30}$ However, the hidden part of confessional education presents a particular religion as having truth and, thus, being in the superior position. Hidden teaching in this educational approach presents a particular religion in a way that the pupil, with the help of the educator, would make a choice for its benefit.

Implicit religious education involves the view that religion can be taught within any curriculum subject because it places focus on the issue that religion can be discovered within any sphere of human experience. ${ }^{31}$ Under this application of educational theory, the educator is introducing a pupil to the existence of faith by which some people live and explains how this faith is seen by this people without stimulation to accept this faith and live by it. ${ }^{32}$ Implicit religious education offers a more liberal approach to religious education.

The philosophical shift from modern to postmodern, as it is described by Siebren Miedema, ${ }^{33}$ David Cooper, ${ }^{34}$ and others, influenced on the transformation of the educational theory, and, consequently, on the development of educational model for the religious education. Robert Jackson, on the example of the works of Dutch scholars Win Wardekker and Siebren Miedema, shows that this philosophical innovation introduced a change from traditionalist's to transmissionist's model of teaching in religious education. ${ }^{35}$ According to the traditionalist's model of religious education, the teaching is based on the abstract "grand narratives" of religious systems. The postmodern shift in religious education is emphasizing the teaching by life-world related questions. According to this model of religious education, as Robert Jackson continues:

Humans are seen as signifiers, while religious rites, practices, doctrines, and narratives are interpreted as cultural artifacts, available to the learner as instruments for guiding thoughts and actions and for reinterpreting ordinary experience. By interacting with religious source material, pupils are offered the possibility of creating personal transformation. Religious rites, practices, doctrines, and narratives are seen as potentially transformative resources of the life-world. Students thus 'take an active part in the construction of new interpretations and new meanings', developing a capacity to integrate different perspectives into their own personality. ${ }^{36}$

\footnotetext{
${ }^{29}$ Sealey, 1985, 43.

${ }^{30}$ Sealey, 1985, 43 and $47-52$.

${ }^{31}$ Sealey, 1985, 43 and 52-60.

${ }^{32}$ Sealey, 1985, 43.

${ }^{33}$ Siebren Miedema, "The End of Pedagogy? A Plea for Concrete Utopian Acting and Thinking," in Postmodernism and Education, P. Higgs, S. Miedema, J.L. van der Walt, and G. Zecha, eds. (conference readings, faculty of education, Potchefstroomse Universiteit vir Christelike Hoër Onderwys, September 1997), 132.

${ }^{34}$ David E. Cooper, "Postmodernism," in A Companion to the Philosophy of Education, Randall Curren, ed. (Oxford, UK: Blackwell Publishing Ltd., 2003), 211.

${ }^{35}$ Robert Jackson, Rethinking Religious Education and Plurality: Issues in Diversity and Pedagogy (London, UK: RoutledgeFalmer, 2004), 58.

${ }^{36}$ Robert Jackson, Rethinking Religious Education and Plurality: Issues in Diversity and Pedagogy, 2004, 58.
} 
As it can be concluded on the base of the above stated thoughts, according to the transmissionist's model of religious education, meanings are never objective, but always depend on the personal relation of a particular individual and its environment.

\section{Religious Education in Relation to Citizenship Education, Moral Education, and Spiritual Education}

According to Colin Alves, different views on educational theory originate from different views of the relationship between the individual and the society he has been born into. ${ }^{37}$ He continues that "if this relationship is seen entirely from the perspective of society, then the task of education will be defined as 'preparation of the pupil to take his place in the society." ${ }^{38}$ In addition, Lyn Tett states that every democratic government aims to ensure that all citizens, regardless of their social or economic background, have opportunities to participate fully in society and enjoy a high quality of life..$^{39}$ The central role in the process of preparation of the individual for taking the appropriate place in the social order falls on education. In addition to this, according to Geoffrey Parrinder, religion has always been present at every level of human society from earliest times ${ }^{40}$ and the question of coexistence of different religious movements takes one of the significant places in multicultural society. Thus, religious education makes not the least contribution to the process of preparation of individuals for the social life. ${ }^{41}$

Beginning the discussion on the relation of religious education to citizenship, moral, and spiritual/ theological education it should be mentioned that all dimensions of education in general are focused on the preparation of the future generations to take the proper place in society and continue the advance of democracy in the world. In this sense all dimensions of education are interconnected and have one common focus - advance of personality and society. Josef Huber, Head of the Council of Europe Pestalozzi Program, speaking on the vision, values, and purpose of education mentioned that "education must be guided by the vision of society we want our children to live in." ${ }^{42}$ Since the contemporary society is characterized by a plurality of opinions on religious faith claims, ways of life and life styles, our vision of the future society we want our children to live in is not monogamous. Therefore, this multiplicity should be reflected in all dimensions of education and be united by them to the common value grounds which we want to place as foundational in our vision for the future of society. As Josef Huber comments:

\footnotetext{
${ }^{37}$ Colin Alves, "Why Religious Education?" in New Movements in Religious Education, Ninian Smart and Donald Horder, eds. (London, Great Britain: Billing \& Sons Ltd., 1978), 23.

${ }^{38}$ Alves, 1978, 23.

${ }^{39}$ Lyn Tett, "Education and Community Health: Identity, Social Justice, and Lifestyle Issues in Communities," in Social Justice, Education, and Identity, Carol Vincent, ed. (London and New York: RoutledgeFalmer, 2003), 83.

${ }^{40}$ Geaffrey Parrinder, World Religions: From Ancient History to the Present (New York, New York: Facts on Time Publications, 1983), 9.

${ }^{41}$ Philipp Klutz, Religious Education Faces the Challenge of Religious Plurality: A Qualitative-Empirical Study in Vienna, trans. Noëmi Lakmaier, Series Religious Diversity and Education in Europe, Cok Bakker, Jenny Berglund, Gerdien Bertram-Troost, Hans-Günter Heimbrock, Julia Ipgrave, Robert Jackson, Geir Skeie, Wolfram Weisse eds., Vol. 32 (Münster, New York: Waxmann, 2016), 24.

${ }^{42}$ Josef Huber, "Seven Theses on Teacher Education and the Purpose of Education," in The EWC Statement Series, European Wergeland Centre, <http://theewc.org/ucontent/the.ewc.statement.series/> (July 9, 2011).
} 
...Do we imagine a society, based on democracy, human rights and the rule of law, a society, which is economically, environmentally, societally and politically sustainable? If we do, then we need education that mobilizes the intellectual and emotional potential of every citizen, so that each can contribute to making this vision become reality.... ${ }^{43}$

All education in the liberal democratic state eventually takes a civic function and prepares individuals for the full and equal citizenship that is required by the liberal democracy. ${ }^{44}$ Bernard Crick and Alex Porter in the report on Program on Political Education give the following definition to citizenship:

Citizenship is knowledge, skills, and attitudes needed to make a man or woman informed about politics and able to participate in public life and groups of all kinds, both occupational and voluntary, and to recognize and tolerate diversities of political and social values. ${ }^{45}$

If citizenship requires a portion of knowledge to be learned for proper application, then, it is a task of education to fulfill this need in society. Moreover, Will Kymlicka says that it is the basic task of schooling (education) to prepare each new generation for their responsibilities as citizens. ${ }^{46}$

In the attempt to meet this social need for the preparation of future citizens, education encounter minor problems. Three inter-related controversies of citizenship education:

- does citizenship education requires common schooling;

- does promoting responsible citizenship requires promoting personal autonomy;

- does promoting a shared civic identity requires teaching not only shared political values or principles but also promoting particular national or cultural identities. ${ }^{47}$

The presented above discussion on problems in religious education shows the danger hidden in education and, specifically, in religious education, if it becomes heavily bound to particular political worldview or to teaching a certain political understanding of good citizenship that is accepted in a given context. ${ }^{48}$ The problem of indoctrination is one of the top issues in the area of connection of religion and society. However, the problem of indoctrination can occur not only in the religious branch of educational theory, but in citizenship or political education as well.

Clear example of indoctrination incorporated into the state system of education is the case of the Soviet Union. State indoctrination in the Soviet Union also touched the

\footnotetext{
${ }^{43}$ Josef Huber, "Seven Theses on Teacher Education and the Purpose of Education," in The EWC Statement Series, European Wergeland Centre, <http://theewc.org/ucontent/the.ewc.statement.series/> (July 9, 2011).

${ }^{44}$ Robert Justin Lipkin, "Pragmatism, Cultural Criticism, and the Idea of the Postmodern University," in $A n$ Ethical Education: Community and Morality in the Multicultural University, M.N.S. Sellers, ed. (Oxford, UK: Berg Publishers, 1994), 77.

${ }^{45}$ Bernard Crick and Alex Porter, Political Education and Political Literacy (Harlow: Longman, 1978),

${ }^{46}$ Will Kymlicka, "Education for Citizenship," in Education in Morality, J. Mark Halstead and Terence H. McLaughlin, ed. (London and New York: Routledge, 1999), 79.

${ }^{47}$ Kymlichka, 1999, 79-80.

${ }^{48}$ Jennifer Fredette, Constructing Muslims in France: Discourse, Public Identity and the Politics of Citizenship (Philadelphia: Temple University Press, 2014), 27.
} 
religious aspect of society of that time, and it shows how political and citizenship, mainly ideological, education was given the priority level over religious and moral education. Religion was considered by the communist ideology to be a vestige of the past ${ }^{49}$ and should be moved out from prominent position in any system or type of education ${ }^{50}$ and, eventually, should cease to exist on the territory of the newly established Union of Socialist Soviet Republics due to its opposing nature to the governmental ideology. It was thought that the weakening of religious beliefs would lead to the strengthening of understanding of citizen responsibilities. However, Jeff Spinner-Halev says completely the opposite idea - that strengthening religious identity does not naturally undermine an idea of common citizenship. ${ }^{51}$ The idea of common citizenship, while not eliminating social, political, cultural, or religious difference, provides an equal ground for debates on citizenship identity and equal opportunities for full participation in the development of the state..$^{52}$

These historical facts and philosophical debates show that philosophical goals of religious and citizenship education - tolerance and faithfulness toward particular belief, ideology, or governmental structure - are similar and that these two educational branches should not oppose each other. When religious or citizenship education takes hostile position toward the other educational branch then such a position testifies about the presence of political or religious indoctrination that could lead to racial, political, or religious aspect of Conservative multiculturalism or Monoculturalism which is not able to tolerate the threat of the cultural/ religious 'other' ${ }^{53}$ However, the ideas of Conservative Multiculturalism or Monoculturalism are not applicable to the idea of citizenship in the contemporary society since living according to commonly observed (religious/ cultural/ ideological) norms or principles becomes not possible..$^{54}$

Concerning the relationship of religious education and moral education, Richard Pring says in Philosophy of Education: Aims, Theory, Common Sense, and Research that all education itself is a moral practice..$^{55}$ The moral practice of educational theory, or education in morality, is high on the agenda of most Western countries that face a moral

\footnotetext{
${ }^{49}$ Will Kymlicka, Education for Citizenship, 1999, 545.

${ }^{50}$ Kymlichka, 1999, 285.

${ }^{51}$ Jeff Spinner-Halev, Surviving Diversity: Religion and Democratic Citizenship (Baltimore, Maryland: The Johns Hopkins University Press, 2000), 127.

${ }^{52}$ Rene Grotenhuis, Nation-Building as Necessary Effort in Fragile States (Amsterdam, The Netherlands: Amsterdam University Press, 2016), 67.

${ }^{53}$ Joel L. Kincheloe and Shirley R. Steinberg, Changing Multiculturalism (Buckingham, Philadelphia: Open University Press, 1997), 3; Daniël J. Louw, "Xenophobia and social prejudice through the lens of Calvin: From 'iron philosophy' to homo sympatheticus in a practical theology of home within the global dilemma of displayed refugees," in Reformed Theology Today: Practical-theological and Ethical Perspectives, Sarel P. van der Walt and Nico Vorster, eds. (Cape Town, South Africa: AOSIS, 2017), 126.

${ }^{54}$ Peter O’Brien, The Muslim Question in Europe: Political Controversies and Public Philosophies (Philadelphia, Rome, Tokyo: Temple University Press, 2016), 67.

${ }^{55}$ Richard Pring, Philosophy of Education: Aims, Theory, Common Sense, and Research (London, New York: Continuum, 2004), 12.
} 
crisis $^{56}$ due to its alternative position toward religious education. ${ }^{57}$ Moral education is designed to produce certain types of persons, with specific virtues, mentalities, habits and skills directed to affect the world in a certain way. ${ }^{58}$ Moral education aims not to understand a world, but to improve it through the moral development of individuals ${ }^{59}$ done by hands of moral educators ${ }^{60}$ However, not all problematic aspects of contemporary society are dealt with in moral education. For example, as Wringe mentions, moral education might address issues as vandalism, burglary, violence, disorderly public behavior, etc. but other equally undesirable things such as speeding, alcohol (ab)use by teens just above the age of legal maturity, "white collar" commercial or governmental crimes that might deprive people of their life savings are rarely included in the curriculum of moral education subjects. ${ }^{61}$

Tim Sprod identifies five dimensions of moral development presented by Matthew in The Philosophy of Childhood:

- a situated, experiential stock of moral paradigms, gradually enriched with further experience, that forms part of the base for moral intuitions, against which the other dimensions may be measured;

- an increasing ability to be able to offer defining characteristics for moral terms that take account of their complexity;

- an increasing ability to judge whether a range of cases fall under a particular moral term;

- a growing sophistication in the adjudication of apparently conflicting claims, when moral intuitions collide;

- a heightening of the moral imagination, based in part on increasing understanding of the world and how it works. ${ }^{62}$

These five dimensions can be generally summarized in the following definition given by Michael Luntley:

Moral education is an education of character, an education of the capacities for belief that turn us from novice to competent judge in matters of value. It is a cumbersome protracted process in which young people acquire the character to

\footnotetext{
${ }^{56}$ David Carr, "Cross Questions and Crooked Answers: Contemporary Problems of Moral Education," in Education in Morality, Mark J. Halstead and Terence H. McLaugblin, eds. (London and New York: Routledge, 1999), 24.

${ }^{57}$ Mark J. Halstead and Terence H. McLaugblin, "Introduction," in Education in Morality, Mark J. Halstead and Terence H. McLaugblin, eds. (London and New York: Routledge, 1999), 1.

${ }^{58}$ Amelie Oksenberg Rorty, "Morality as an Educational Institution," in Education in Morality, Mark J. Halstead and Terence H. McLaugblin, eds. (London and New York: Routledge, 1999), 8.

${ }^{59}$ Rorty, 1999, 9.

${ }^{60}$ Richard Pring, Philosophy of Education: Aims, Theory, Common Sense, and Research, 2004, 12.

${ }^{61}$ Colin Wringe, Moral Education: Beyond the Teaching of Right and Wrong, Vol. 14, Series Philosophy and Education (Netherlands, Springer, 2006), 12.

${ }^{62}$ Tim Sprod, Philosophical Discussion in Moral Education: The Community of Ethical Inquiry (London and New York: Routledge, 2001), 90.
} 
become judges equipped with the sensibility that renders them capable of passing judgment upon the particular contingencies of life, a judgment that is susceptible for evaluation by the ordinary standards of truth and falsity. Moral education is a nurturing of young people into a position of shared responsibility for the way we make our world and the values by which we live. ${ }^{63}$

In most known societies moral education takes place under the auspices of a religious outlook which provides the cognitive and affective framework for it. ${ }^{64}$ Because of this slight overlap in goals, some philosophers of education say that moral education is rather a peripheral part of education. ${ }^{65}$

The third educational branch that will be compared in this section to religious education is spiritual education. Spiritual education could be considered as a part of education in religion aimed on fulfilling the spiritual hunger of humanity, strengthening the faith of practitioners of a particular religion, and developing the learners spiritually. ${ }^{66}$ Spiritual education stresses the personal application of faith in the daily life. Some philosophers of religion and education and some educators argues that religious and spiritual education are one in their essence and these two terms can be used synonymously. ${ }^{67}$ Other party holds to the view that the terms "spiritual" and "religious" are not synonyms because there is a clear distinguish between them. ${ }^{68}$ Religious education might or might not touch the spiritual aspect of the life of individual; and from the other side, spiritual development of individuals might or might not be religious. ${ }^{69}$ The National Curriculum Council in United Kingdom distinguishes the following aspects of spiritual development:

- the development of personal beliefs that may or may not be specifically religious;

- a sense of awe, wander, and mystery;

- experiencing of feelings of transcendence;

- a search for meaning and purpose;

- self-knowledge;

- recognizing the worth of individuals and building relationship with others;

- experiencing one's innermost thoughts through the arts and experiencing the imagination;

- feelings and emotions;

- $\quad$ a sense of being moved. ${ }^{70}$

\footnotetext{
${ }^{63}$ Michael Luntley, "Postmodernism and the Education of Character," in Education in Morality, J. Mark Halstead and Terence H. McLaughlin, ed. (London and New York: Routledge, 1999), 188.

${ }^{64}$ Christopher Winch, The Philosophy of Human Learning (London and New York: Routledge, 1998), 159.

${ }^{65}$ Graham Haydon, "Moral Education," in A Companion to the Philosophy of Education, Randall Curren, ed. (Oxford, UK: Blackwell Publishing Ltd., 2003), 320.

${ }^{66}$ Alfred A. McBride and O. Praem, Creative Teaching in Christian Education (Boston, Massachusetts: Allyn and Becon Inc., 1978), 86.

${ }^{67}$ McBride and Praem, 1978, 86-89.

${ }^{68}$ Alex Rodger, "Moral, Spiritual, Religious - Are They Synonymous?" in Spiritual and Religious Education, vol. V, Education, Culture, and Values, Mal Leicester, Celia Modgil, and Sohan Modgil, eds. (London, UK: Falmer Press, 2000), 3.

${ }^{69}$ David Adshead, "Facilitating Spiritual Development in the Context of Cultural Diversity," in Spiritual and Religious Education, vol. V, Education, Culture, and Values, Mal Leicester, Celia Modgil, and Sohan Modgil, eds. (London, UK: Falmer Press, 2000), 27.

${ }^{70}$ Adshead, 2000, 27.
} 
Spiritual education is directed toward the development of personal inner being of the individual. This inner being of the individual could find its expression through following different religious beliefs or practicing different religious traditions and customs. However, the personal spiritual development of the individual is not tied to a specific religious movement or religion at all. The spiritual development of the individual can be achieved, for example, by meditating on works of arts or through observing nature. The way to come to the point of spiritual maturity can vary from individual to individual. Therefore, to some extent, liberal spiritual education can be considered a postmodern approach to religious education when truth loses its absolutism and becomes dependent on the personal experience of the individual.

Table 4: Comparison of Religious Education to Spiritual, Moral, and Citizen Education*

\begin{tabular}{|l|l|l|}
\hline & \multicolumn{1}{|c|}{ Aims } & \multicolumn{1}{|c|}{ Concerns } \\
\hline $\begin{array}{l}\text { Religious } \\
\text { education }\end{array}$ & $\begin{array}{l}\text { Aims on passing the knowledge about religion } \\
\text { so that every learner would acquire necessary } \\
\text { practical, experiential, or sacramental skills } \\
\text { to gain a personal understanding of particular } \\
\text { religious beliefs }\end{array}$ & $\begin{array}{l}\text { Concerns with passing religious } \\
\text { knowledge or knowledge about } \\
\text { religion to broader understanding } \\
\text { about religion }\end{array}$ \\
\hline $\begin{array}{l}\text { Citizenship } \\
\text { education }\end{array}$ & $\begin{array}{l}\text { Aims on developing an understanding of dis- } \\
\text { tinctive identity of shared membership in the } \\
\text { society and on increasing an affective bond to } \\
\text { the policy of this community2) }\end{array}$ & $\begin{array}{l}\text { Concerns with social develop- } \\
\text { ment of citizens that plays a } \\
\text { crucial role in shaping the future } \\
\text { of democracy }\end{array}$ \\
\hline $\begin{array}{l}\text { Moral } \\
\text { education }\end{array}$ & $\begin{array}{l}\text { Aims on equipping people with the knowledge } \\
\text { and understanding to enable them to think and } \\
\text { chose for themselves on moral matters }\end{array}$ & $\begin{array}{l}\text { Concerns with moral develop- } \\
\text { ment of individuals to secure } \\
\text { a ethically and morally correct } \\
\text { structures in the society }\end{array}$ \\
\hline $\begin{array}{l}\text { Spiritual } \\
\text { education }\end{array}$ & $\begin{array}{l}\text { Aims on filling the vacuum of spiritual hunger } \\
\text { of a community of believers within a circle of } \\
\text { religion or outside of it and leads to spiritual } \\
\text { growth caused by the increase of spiritual faith- } \\
\text { knowledge }\end{array}$ & $\begin{array}{l}\text { Concerns with spiritual develop- } \\
\text { ment of individuals; if it is done } \\
\text { within the specific religious } \\
\text { tradition then it concerns with } \\
\text { spiritual development of individu- } \\
\text { als to strengthen religion }\end{array}$ \\
\hline
\end{tabular}

*Due to the focus of the article the following research will mostly deal with the correlation between religious and citizenship education. The sections on moral and spiritual education are presented as informative for the purpose to indicate the difference between these dimensions of education.

1) Adapted from Christopher Winch, The Philosophy of Human Learning, 1998, 152.

2) Adapted from Melissa S. Williams, Citizenship as Identity, Citizenship as Shared Fate, and the Function of Multicultural Education, in "Citizenship and Education in Liberal-Democratic Societies: Teaching for Cosmopolitan Values and Collective Identities," Kevin McDonough and Walter Feinberg, eds. (New York, New York: Oxford University Press Inc., 2003), 209-210.

3) Henry A. Giroux, Introduction: Modernism, Postmodernism, and Feminism - Rethinking the Boundaries of Educational Discourse, in "Postmodernism, Feminism, and Cultural Polotics," Henry A. Giroux, ed. (New York, New York: State University New York Press, 1991), 1.

4) Graham Haydon, Moral Education, in "A Companion to the Philosophy of Education," Randall Curren, ed. (Oxford, UK: Blackwell Publishing Ltd., 2003), 323.

5) Adapted from Alfred A. McBride, O. Praem, Creative Teaching in Christian Education, 1978, 86. 
During the past century the violent interaction between various people groups and intolerant attitudes has increased to the extent that the contemporary society has witnessed "death on a mass" ${ }^{71}$ These placed a high demand on implementation of conception of tolerance and mutual living together in present day society through the help of education. ${ }^{72}$ Ideals of tolerance, mutual living together, dialogue, and cooperation became one of the most integral principles in the pedagogical practice of religious education. ${ }^{73}$ However, these ideas are not the monopoly of religious education alone; they are also reflected in citizenship education. According to Wolfram Weisse there is a direct correlation between religious education and democratic conduct. As Weisse mentions in reference to Hasenclever, "the lesser degree of religious education, the greater is the potential for religious differences to be instrumentalised as a tool for political mobilization." 74 Therefore, the necessity of interreligious dialogue is equally included in religious and citizenship dimensions of education. For example, the approach developed by Wolfram Weisse focused on a slight combination of religious education with education for citizenship..$^{75}$

The understanding of correlation between religious and citizenship education is necessary for research on the models of religious education as applied to political structures existing in the state and the factors influencing on their development. ${ }^{76}$ To a certain extent, relation between religion and the idea of citizenship and to what extend religion and religious plurality influences the (formation of) idea of citizenship is quite crucial for all multicultural communities and is one of the contested issues in contemporary society. ${ }^{77}$

\section{Religious and Pedagogical Dimensions and Diversity in Religious Education}

As it is presented in the sections above, there is a great deal of debate on the relation between education and religion in the area of religious education. Some experts define religious education as a direct fusion of religion and education that separately developed into self-standing philosophical branch. However, the other group argues that religious education is more than just a fusion of religion and education. ${ }^{78}$

\footnotetext{
${ }^{71}$ Liam Gearon, "The Teaching of Human Rights in Religious Education: The Case of Genocide," in Education, Religion and Society: Essays in Honour of John M. Hull, Dennis Bates, Gloria Durka and Friedrich Schweitzer, Series Routledge Research in Education (London and New York: Routledge, 2006), 79.

${ }^{72}$ Siebren Miedema, "Contexts, Debates and Perspectives of Religion in Education in Europe," in Religion and Education in Europe: Developments, Contexts and Debates, Robert Jackson, Siebren Miedema, Wolfram Weisse, Jean-Paul Willaime, eds., vol. 3, Series Religious Diversity and Education in Europe (Münster, Waxmann, 2007), 267.

${ }^{73}$ Gearon, 2006, 76.

${ }^{74}$ Hasenclever in Wolfram Weisse, 2007, 9.

${ }^{75}$ Robert Jackson, Intercultural Education and Religious Education, 2006, 57.

${ }^{76}$ Peter Schreiner, "Relihioznoe Obrazovanie v Evropejskom Kontekste [Religious Education in European Context]," in Religious Education in Europe: Situatio and current trends in schools, Elza Kuyk, Roger Jensen, David Lankshear, Elisabeth Löh Manna, and Peter Schreiner, eds., trans., Aleksandr Judin (Kyiv: Duh i Litera, 2013), 14.

${ }^{77}$ Veit Bader, Secularism or Democracy? Associational Governance of Religious Diversity, IMISCOE Research (Amsterdam, The Netherlands: Amsterdam University Press, 2007), 155.

${ }^{78}$ Timothy Arthur Lines, Functional mages of the Religious Educator (Birmingham, Alabama; Religious Education Press, 1992), 15.
} 
Figure 5.A: Religious Education as Fusion of Religion and Education

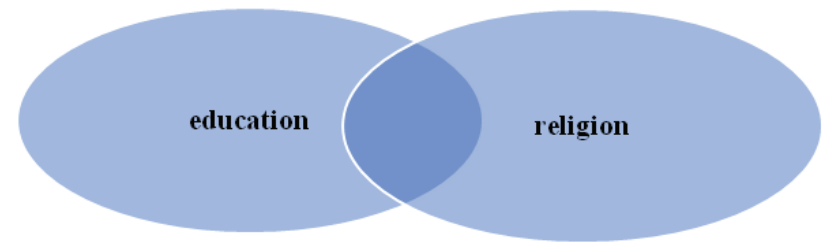

\section{Religious education}

Lines, 1992, p. 15.

The combination of religion and education is based on the needs of religion in education. All religions, being started, have a need to continue their influential existence by involving more practitioners and teaching them the values and faith-claims of the religion. One of the ways to achieve growth and development of that or another particular religion is hidden in the use of education.

There are two basic needs of religion in education: sequential need and social need. The natural character of religion to continue its existence and to develop into strong influential structure describes the sequential need. Sequential need of religious community is directly connected to the (religious) identity of that community, i.e. "core values capture shared ambitions" ${ }^{79}$ When this need is not fulfilled, religious community experiences threat that their values (and ideologies) are disintegrated or being challenged by the rest of the society. ${ }^{80}$ One of the dimensions of religion is that it has doctrines or beliefs in its foundation. ${ }^{81}$ Doctrines or beliefs are related to the branch of epistemology (something what practitioners should know) even if it is built on experiential phenomenon (something what practitioners experienced). Thus, religious doctrines, being a branch of epistemology, need an educational theory to be learned by practitioners. Therefore, in order to fulfill the sequential need, religion should seek the help of education.

The second basic need of education in religion, the social need, is initiated by the desire of religion to be open for public observation in order to draw the attention of newcomers. The race for attractiveness to newcomers makes leaders of a religion to understand the necessity to explain and present their beliefs in the form acceptable by the public. However, to be acceptable, the religion needs to be understandable. The need for clarity sometimes influences religion to use or to adapt the secular or "non-spiritual" means of explanations. The use of secular systems or methods of education is one of those occasions of use of "non-spiritual" means of explanations. Nevertheless, the implication of "non-spiritual" educational theories in the religion can also create problems for religion itself. Sometimes

\footnotetext{
${ }^{79}$ Bert van der Zwaan, Higher Education in 2040: A Global Approach (Amsterdam, The Netherlands: Amsterdam University Press, 2017), 186.

${ }^{80}$ Jahannes Janse van Rensburg, "An Assessment of the Theology of Religions," in Perspectives of Theology of Religions, Jaco Beyers, eds., Series Teologiese Studies, Supplementun 12 (Cape Town, South Africa: AOSIS, 2017), 98.

${ }^{81}$ Melchert, 1994, 55.
} 
religion goes to the extreme in that educational theories should not be used in religion at all because "the education cannot redeem a society." ${ }^{\text {" }}$ People who ask questions like, for example, "Why should Christians borrow a system of education from the secular world?" 83 are not considering the fact that the original beginning of education was the divine desire of human beings to know more about their origin, purpose, and role in the universe.$^{84}$ In other words, epistemological desires of human beings initiated education. The same epistemological desires to explain such phenomenon as death and all what is not comprehended emerge from the origin for all existing religions. Therefore, religion needs education to serve as a tool to help religion be understandable.

The combination of religion and education also creates a problem for educational theory. This problem is presented by a controversy between "sophisticated" and "primitive" concepts of education. ${ }^{85}$ The "sophisticated" concept of education is determined by the idea that "education should not be limited by what any group simply believes, but by what on publicly acknowledged rational grounds we can claim to know and understand." The "primitive" concept of education simply concerns "passing on to children what we believe, so that they in their turn come to believe it to be true."

Some philosophers of education, who hold to "sophisticated" concept of religious education, say that religious education should not be called an application of educational theory at all. Religious education, being already defined by a specific group of beliefs or doctrines, is not an education because "any form of religious nurture is not properly educational." ${ }^{86}$ Glen Ross says in her article Metaphysical Skepticism and the Teaching of Philosophy that any kind of religious or philosophical education should be of a neutral position:

The teaching of philosophy is thought to require a certain form of neutrality. A philosophy teacher should not take it as a goal of a teaching of philosophy that students be converted to any particular philosophical doctrine, or that they be sustained in any of their preexisting opinions... Instead, the successful teacher of philosophy forces students to think critically about a philosophical position and its competitors. ${ }^{87}$

Therefore, religious education should have an "open-mind" direction with a critical approach; otherwise, it would lead to the danger of indoctrination (simple creation of narrow-minded practitioners). However, philosophers who hold to the "primitive" concept of religious education, say that the simple transition of religious beliefs and doctrines meets the sequel need of religion, and thus, is of a more value for the religion. Also, the

\footnotetext{
${ }^{82}$ Kenneth O. Gangel and Warren S. Benson, Christian Education: Its History and Philosophy (Chicago: Moody Press, 1983), 357.

${ }^{83}$ Lois E. Lebar, Education that is Christian (Colorado Springs, Colorado: Chariot Victor Publishing, 1995), 25.

${ }^{84}$ Jeff Astley, "Reason, Religion and Education: An Overview," in Critical Perspectives on Christian Education, Jeff Astley and Leslie J. Francis, eds. (Melksham, Wiltshire: The Cromwell Press, 1994), 295.

${ }^{85}$ Astley, The Philosophy of Christian Religious Education, 1994, 41.

${ }^{86}$ Astley, 1994, 41.

${ }^{87}$ Glen Ross, "Metaphysical Skepticism and the Teaching of Philosophy," in Knowledge, Teaching, and Wisdom, Keith Lehrer, B. Jeannie Lum etc., eds., Philosophical Studies Series 67 (Dordrecht, The Netherlands: Kluwer Academic Publishers, 1996), 245.
} 
"primitive" concept of religious education reminds its opponents that all education is of a divine origin and is firstly called to fulfill the divine epistemological concerns of an individual.

"Primitive" and "sophisticated" concepts of education being of a different purpose and target require the use of dissimilar models of educational theory. The chart below presents a brief overview of four models of educational theories and their connection to "primitive" and "sophisticated" concepts of education.

Table 5.B: Four Theories of Religious Education in Correlation to Primitive and Sophisticated Concepts of Education

\begin{tabular}{|c|c|c|}
\hline $\begin{array}{l}\text { Theory of } \\
\text { Religious } \\
\text { Education }\end{array}$ & Description & $\begin{array}{l}\text { Concept of } \\
\text { Religious } \\
\text { Education }\end{array}$ \\
\hline $\begin{array}{l}\text { Education I } \\
\text { Traditionalists } \\
\text { Theory }\end{array}$ & $\begin{array}{l}\text { Concern with transmission of specific beliefs, } \\
\text { values, skills, etc. within a particular tradition in a } \\
\text { highly conservative fashion }\end{array}$ & \multirow{2}{*}{ 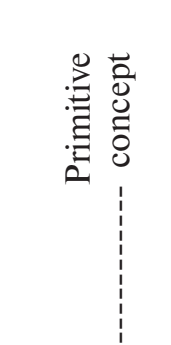 } \\
\hline $\begin{array}{l}\text { Education II } \\
\text { Progressivists Theory }\end{array}$ & $\begin{array}{l}\text { Slight adaptation of "Critical rational" approach; } \\
\text { sometimes it splits into two approaches - one } \\
\text { with application of critical discussions, the other } \\
\text { stresses catechesis and indoctrination }\end{array}$ & \\
\hline $\begin{array}{l}\text { Education III } \\
\text { Presuppositionists } \\
\text { Theory }\end{array}$ & $\begin{array}{l}\text { Autonomous belief claims are allowed sometimes, } \\
\text { but only in presupposition-based "tradition" }\end{array}$ & \multirow{2}{*}{ 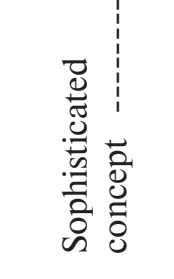 } \\
\hline $\begin{array}{l}\text { Education IV } \\
\text { Rationalists Theory }\end{array}$ & $\begin{array}{l}\text { All beliefs, values, and attitudes are subject to } \\
\text { rational criticism }\end{array}$ & \\
\hline
\end{tabular}

Vitaliy V. Proshak, A Philosophy of Religious Education in an Pluralist Society: Christian Evangelical Education in Ukraine Since 1991, 2007, p. 29.

These various philosophies of (religious) education also influenced the development of other education thoughts. For example, Montessori believed that children have no need of the formal instruction at all; rather it is they, if placed in a favorable environment, who will unveil their inner image of man designed by the Creator, reveal their hidden human powers and will come to the fullness of life, of course, if their souls were not harmed. Montessori believed in the combined application of the scientific and religious truth. ${ }^{88}$

\footnotetext{
${ }^{88}$ Rita Kramer, Maria Montessori (NY: G.P.Putnam, 1976), p. 251, quoted by Jerome Berryman, "Montessori and Religious Education", in Religious Education, 75:3 (1980:May/June), p. 295.
} 
Table 5.C: Variety of Models and Approaches in Religious Education

\begin{tabular}{|c|c|}
\hline \multicolumn{2}{|c|}{ Separate subject vs. Several subjects } \\
\hline $\begin{array}{l}\text { Separate subject } \\
\text { Religion as the main topic of the subject; } \\
\text { specifically dedicated to studying religion. }\end{array}$ & $\begin{array}{l}\qquad \text { Several subjects } \\
\text { Religion as a subtheme in each subject; } \\
\text { subjects are not specifically dedicated to } \\
\text { studying religion. }\end{array}$ \\
\hline \multicolumn{2}{|c|}{ Contextualized vs. Non-Contextualized } \\
\hline Contextualized view & Non-Contextualized view \\
\hline $\begin{array}{l}\text { Subject is connected to the personal view of } \\
\text { the pupil; education in religion. }\end{array}$ & $\begin{array}{l}\text { Subject has no connection to the personal } \\
\text { view of the pupil; education about religion. }\end{array}$ \\
\hline \multicolumn{2}{|c|}{ Particular vs. General } \\
\hline Particular view & General view \\
\hline $\begin{array}{l}\text { Subject treats each religious tradition sepa- } \\
\text { rately; education in/ about religion. }\end{array}$ & $\begin{array}{l}\text { Subject treats religious traditions as diverse } \\
\text { philosophical movement based on com- } \\
\text { mon values and offers no overview of reli- } \\
\text { gious particular individualities; education } \\
\text { about religion/ religious facts. }\end{array}$ \\
\hline \multicolumn{2}{|c|}{ Confessional vs. Non-Confessional } \\
\hline Confessional education & Non-Confessional education \\
\hline $\begin{array}{l}\text { Focuses on study of a particular religious her- } \\
\text { itage; underlines exclusiveness/ inclusiveness/ } \\
\text { pluralistic attitude toward other traditions. }\end{array}$ & $\begin{array}{l}\text { Focuses on study of diversity of religious } \\
\text { traditions; underlines unifying features in } \\
\text { diversity. }\end{array}$ \\
\hline \multicolumn{2}{|c|}{ Pluralistic vs. Relativistic } \\
\hline Pluralistic approach & Relativistic approach \\
\hline $\begin{array}{l}\text { Offers overview in diversity of religious tradi- } \\
\text { tions, view, philosophies; focuses on unifying } \\
\text { features/ values in religious multiplicity. }\end{array}$ & $\begin{array}{l}\text { Offers overview of diversity of religious tra- } \\
\text { ditions, view, philosophies without focus- } \\
\text { ing on their diversity; makes no distinction } \\
\text { in features/ values of different religious } \\
\text { traditions. }\end{array}$ \\
\hline
\end{tabular}

Therefore, as the above presented sections reveal, religious education is not a faceless monolith of educational idea and praxis. Religious education, being in interconnection between educational philosophies and religious diversity, is a unity of multidimensional variety of theories, methods, models, approaches, and practices.

\section{Models of Religious Education According to the REDCo Project}

"It takes time to sense the climate of religious education in Europe. Each country has its own traditions, deeply established in the past and yet violently altered by recent 
events." - wrote Randolph Crump Miller in the sixties of the last century; and yet, these words are more than just relevant in our contemporary time of the year of $2018{ }^{89}$ For the several past decades religious education was at the focus of national and international attention of researchers, policy makers, educators, politicians, and, not the least, parents of school children.

However, in spite of being in the center of the public attention, religious education, and religion in general, is hardly a central leading force in the public societal sphere of various Eastern European states. The attitude toward religion is seen differently in the various European state ${ }^{90}$ and varies from intentions to place it as a foundational feature of national constitutions, as in the case of Hungary, ${ }^{91}$ to being preserved in national memories as historical past.

As it was already mentioned above, the Council of Europe is already involved in research in this area for at least the last three decades. The overview of some research projects that are relevant for this proposal is presented in the table below. However, these research projects were/ are focused mainly on Western European countries.

Table 6.A: (Some of) Council of Europe Projects on Religious Education

\begin{tabular}{|c|c|}
\hline Project & Explanation \\
\hline $\begin{array}{l}\text { The New Challenge of Inter- } \\
\text { cultural Education: } \\
\text { Religious Diversity } \\
\text { and Dialogue in Europe } \\
\text { 2002 }\end{array}$ & $\begin{array}{l}\text { Relation of religion to culture } \\
\text { Cultural Argument for religious education: } \\
\text { regardless of being true or false, religion is a part } \\
\text { of a culture (national/ international); therefore, } \\
\text { religion should be understood by all citizens of a state }\end{array}$ \\
\hline $\begin{array}{l}\text { Religion and Education: } \\
\text { Dialogue or Conflict? } \\
\text { (REDCo) CoE, } \\
\text { Framework } 6 \\
\mathbf{2 0 0 6}\end{array}$ & $\begin{array}{l}\text { Relation of religion to education } \\
\text { Conflict Resolution Argument for religious } \\
\text { education: study of religion at school can help } \\
\text { to promote multicultural dialogue and reduce conflict } \\
\text { in society; therefore, religion should be a part } \\
\text { of conflict resolution strategy }\end{array}$ \\
\hline
\end{tabular}

According to the research of Jean-Paul Willaime within the project of the REDCo group, three main models of religious education exist within the European continental boarders; other situations with religious education are variable combinations

\footnotetext{
89 Randolph Crump Miller, "Religious Education in Europe," in Religious Education, 55:2 (1960: Jan/Dec.), 141.

${ }^{90}$ Robert Jackson, "European Institutions and the Contribution of Studies of Religious Diversity to Education for Democratic Citizenship," in Religion and Education in Europe: Developments, Contexts and Debates, Robert Jackson, Siebren Miedema, Wolfram Weisse, Jean-Paul Willaime, eds., vol. 3, Series Religious Diversity and Education in Europe (Münster, Waxmann, 2007), 28.

${ }^{91}$ RISU, U 2012 Rotsi Ugortshina Pochne Zhuty za Novoju Konstitutsieju, Zasnovanoju na Christianskih Tsinnostiah [In 2012 Hungary will Start to Live According to the New Constitution, Which is Based on the Christian Values], 27-03-2011, <www.risu.org.ua> (July 1, 2011).
} 
of them..$^{92}$ The table presented below provides a general overview of the aforementioned REDCo models of religious education: (1) no religious education, (2) confessional religious education and (3) non- confessional religious education. In short, the main difference between these various models of religious education is the state attitude toward religious plurality. Consequently, the model applied testifies about the level of tolerance toward religious variety and the level of democracy exercised in the governmental structures.

Table 6.B: Existed Models of Religious Education in Europe

\begin{tabular}{|l|l|}
\hline \multicolumn{1}{|c|}{ Model Named } & \multicolumn{1}{c|}{ Model Described } \\
\hline $\begin{array}{l}\text { No religious } \\
\text { education }\end{array}$ & $\begin{array}{l}\text { No religious instruction in state schools, substituted } \\
\text { with humanistic or ideological education which are directed } \\
\text { toward citizenship development }\end{array}$ \\
\hline $\begin{array}{l}\text { Confessional } \\
\text { religious } \\
\text { education }\end{array}$ & $\begin{array}{l}\text { The right of religious instruction belong to a particular chosen } \\
\text { religious group; religious groups outside of preferred religious } \\
\text { tradition might have an option of being involved in private } \\
\text { sphere of religious education; the privileged position of this } \\
\text { religious group defined by historic, ethnic, or cultural } \\
\text { ties with the particular society }\end{array}$ \\
\hline $\begin{array}{l}\text { Non-confessional } \\
\text { religious } \\
\text { education }\end{array}$ & $\begin{array}{l}\text { The right of religious instruction belong to many/ or all reli- } \\
\text { gious groups and organizations existed in the particular society; } \\
\text { religious education can be delivered in public or private } \\
\text { sector of education }\end{array}$ \\
\hline
\end{tabular}

Proshak, 2010, 117.

Since future peace and security, as Gabriel Moran states, depends not just on politics, economics, and technology, but on the "successful transformation of religious education," ${ }^{93}$ the application of the right model of religious education could possibly contribute toward the development of democracy, tolerance and mutual living together.

Commenting on the level of interaction between religion, society, education, and governmental structures, Josef Huber mentions that these ideas are highly interconnected; however, this interconnection is not always recognized and often neglected:

...Education does not happen in a vacuum, education policy makers and education practitioners both are anchored in a society and in views about what

\footnotetext{
${ }^{92}$ Jean-Paul Willaime, "Different Models for Religion and Education in Europe," in Religion and Education in Europe: Develpments, Context, and Debates, Robert Jackson, Siebren Miedema, Wolfram Weisse, Jean-Paul Willaime, eds., series Religious Diversity and Education in Europe, Cok Bakker, Hans-Günter Heimbrock, Robert Jackson, Geir Skeie Wolfram Weisse, eds., vol 3 (Münster, New York; München, Berlin: Waxman, 2007), 60; Wanda Alberts, "Integrative Religious Education in Europe: A Study-of-Religions Approach," in Religion and Reason, Winnifred Fallers Sullivan, ed, Vol. 47 (Germany, Berlin: Walter de Gruyter, 2007), 317. ${ }^{93}$ Moran, 2006, 38.
} 
is and what it is not desirable for the present and for the future of this society

(whether they say so or not)....94

As it is mentioned in the section above, the model of religious education applied testifies about the level of tolerance and democracy exercised in a particular state. It means that there is a high level of connection between Church - State model and a model of religious education.

\section{Conclusion}

This discussion of the theory, methodology and praxis of religious education in the context of public secondary schools reveals that religious educational theory is the result of the combination of the needs of religion and the means of the divine desire of human beings for epistemology. In conclusion to this article it is necessary to highlight a few important issues in the development of religious educational theory.

First, it is important to look on religious education as a helping tool in understanding religious claims, doctrines, and beliefs. In a sense, religious education fulfills the role of the tool for nurturing and the upbringing of individuals inside a particular religious tradition. At the same time, religious education helps religion to explain its beliefs and doctrines to individuals outside of it. If it is necessary, religious education also becomes a tool for presenting philosophical explanations to defend religious claims.

Second, it is also significant to notice that religious education fulfills the needs of religion. Consequently, religious education fulfills the sequel and social needs of a religious philosophical tradition or movement. Religious education, in the application to the primitive concept of education, provides an educational system to transmit religious beliefs to future generations. On the other hand, religious education invites an individual to adopt a sophisticated neutral approach to education and explore its beliefs.

Third, it is important to realize that in light of religious and cultural diversity brought by contemporary globalization, a high demand is placed on religious dimension of education to contribute toward increase of tolerance and mutual living together. Religious faithclaims, being in diversity to each other, could provide a unifying base for contemporary and future society if taught in a right perspective.

Therefore, as this article shows, religious education plays an essential role in the life of contemporary society. Treatment of religious education by state could testify about democracy development of the state itself. Thus, developing healthy approach to religious education, is an essential component of democracy development of the state structures.

\footnotetext{
${ }_{94}^{4}$ Josef Huber, "Seven Theses on Teacher Education and the Purpose of Education," in The EWC Statement Series, European Wergeland Centre, <http://theewc.org/ucontent/the.ewc.statement.series/> (July 9, 2011).
} 


\section{BIBLIOGRAPHY}

Abba, Raymond. "Athens and Jerusalem: Religious Studies in the Secular University". An open lecture at California State University, Fullerton, California, May 8, 1974. Religious Education, 70:4, (1975, July/ August): 355-374.

Adshead, David. "Facilitating Spiritual Development in the Context of Cultural Diversity". In Spiritual and Religious Education. Vol. V, Education, Culture, and Values, Mal Leicester, Celia Modgil, and Sohan Modgil, eds. London, UK: Falmer Press, 2000.

Alberts, Wanda. "Integrative Religious Education in Europe: A Study-of-Religions Approach.” In Religion and Reason, Winnifred Fallers Sullivan, ed. Vol. 47. Germany, Berlin: Walter de Gruyter, 2007.

Alves, Colin. “Why Religious Education?” In New Movements in Religious Education, Ninian Smart and Donald Horder, eds. London, Great Britain: Billing \& Sons Ltd., 1978.

Astley, Jeff. "Reason, Religion and Education: An Overview." In Critical Perspectives on Christian Education, Jeff Astley and Leslie J. Francis, eds. Melksham, Wiltshire: The Cromwell Press, 1994.

Astley, Jeff. The Philosophy of Christian Religious Education. Birmingham, Alabama; Religious Education Press, 1994.

Avest, Ina ter, Cok Bakker, and Anna van der Want. "International Comparison Commonalities and Differences of 36 Teachers Teaching Religion(s) in Europe." In Teachers Responding to Religious Diversity in Europe, Anna van der Want, Cok Bakker, Ina ter Avest, Judith Everington, eds. Vol. 8, Series Religious Diversity and Education in Europe. Münster, Waxmann, 2009.

Avest, Ina ter. “Conflict Matters: 'The Making of' a Difference.” In Education in Conflict, Ina ter Avest, ed. Vol. 9, Series Religious Diversity and Education in Conflict. Münster, Waxmann, 2009.

Bader, Veit. Secularism or Democracy? Associational Governance of Religious Diversity. IMISCOE Research. Amsterdam, The Netherlands: Amsterdam University Press, 2007.

Bakker, Cok and Karin Griffioen. "Introduction to the Religious Dimensions in Intercultural Education." Religious Dimensions in Intercultural Education: Theory and Good Practice. Cok Bakker and Karin Griffioen, eds. Netherlands: Dutch University Press, 2001.

Berryman, Jerome. "Montessori and Religious Education." Religious Education, 75:3 (1980:May/June): 294-307.

Bigger, Stephen. "Religious Education, Spirituality, and Anti-Racism.” In Education, Culture, and Value, vol. V, Spiritual and Religious Education, Mal Leicester, Celia Modgil, and Sohan Modgil, eds. London and New York: Falmer Press, 2000.

Carr, David. "Cross Questions and Crooked Answers: Contemporary Problems of Moral Education." In Education in Morality, Mark J. Halstead and Terence H. McLaugblin, eds. London and New York: Routledge, 1999. 
Cooper, David E. “Postmodernism.” In A Companion to the Philosophy of Education, Randall Curren, ed. Oxford, UK: Blackwell Publishing Ltd., 2003.

Crick, Bernard and Alex Porter. Political Education and Political Literacy. Harlow: Longman, 1978.

Fredette, Jennifer. Constructing Muslims in France: Discourse, Public Identity and the Politics of Citizenship. Philadelphia: Temple University Press, 2014.

Gangel, Kenneth O. and Warren S. Benson. Christian Education: Its History and Philosophy. Chicago: Moody Press, 1983.

Gearon, Liam. "The Teaching of Human Rights in Religious Education: The Case of Genocide." In Education, Religion and Society: Essays in Honour of John M. Hull, Dennis Bates, Gloria Durka and Friedrich Schweitzer. Series Routledge Research in Education. London and New York: Routledge, 2006.

Giroux, Henry A. "Introduction: Modernism, Postmodernism, and Feminism - Rethinking the Boundaries of Educational Discourse." In Postmodernism, Feminism, and Cultural Politics, Henry A. Giroux, ed. New York, New York: State University New York Press, 1991.

Groom, Thomas H. Christian Religious Education: Sharing Our Story and Vision. New York, NY; HarperSanFrancisco, 1981.

Grotenhuis, Rene. Nation-Building as Necessary Effort in Fragile States. Amsterdam, The Netherlands: Amsterdam University Press, 2016.

Halstead, Mark J. and Terence H. McLaugblin. “Introduction.” In Education in Morality, Mark J. Halstead and Terence H. McLaugblin, eds. London and New York: Routledge, 1999.

Haydon, Graham. "Moral Education.” In A Companion to the Philosophy of Education, Randall Curren, ed. Oxford, UK: Blackwell Publishing Ltd., 2003.

Hick, John. "The Contribution of the Philosophy of Religion to Religious Education." In Education, Religion, and Society: Essays in Honour of John M. Hull, Dennis Bates, Gloria Durka, and Friederich Schweitzer, eds. Series Routledge Research in Education. London and New York; Routledge, Taylor \& Francis Group, 2006.

Huber, Josef. "Seven Theses on Teacher Education and the Purpose of Education." The EWC Statement Series, European Wergeland Centre, <http://theewc.org/ucontent/the.ewc. statement.series/> (July 9, 2011).

Jackson, Robert. "European Institutions and the Contribution of Studies of Religious Diversity to Education for Democratic Citizenship." In Religion and Education in Europe: Developments, Contexts and Debates, Robert Jackson, Siebren Miedema, Wolfram Weisse, Jean-Paul Willaime, eds. Vol. 3, Series Religious Diversity and Education in Europe. Münster, Waxmann, 2007.

Jackson, Robert. Intercultural Education and Religious Education, 2006.

Jackson, Robert. Religious Education: An Interpretive Approach, $5^{\text {th }}$ reprint. Great Britain, London: Hodder and Stoughton Education, 2003 [1997]. 
Jackson, Robert. Rethinking Religious Education and Plurality: Issues in Diversity and Pedagogy. London, UK: RoutledgeFalmer, 2004.

Kincheloe, Joel L. and Shirley R. Steinberg. Changing Multiculturalism. Buckingham, Philadelphia: Open University Press, 1997.

Klutz, Philipp. Religious Education Faces the Challenge of Religious Plurality: A QualitativeEmpirical Study in Vienna. Trans. Noëmi Lakmaier. Series Religious Diversity and Education in Europe, Cok Bakker, Jenny Berglund, Gerdien Bertram-Troost, HansGünter Heimbrock, Julia Ipgrave, Robert Jackson, Geir Skeie, Wolfram Weisse eds. Vol. 32. Münster, New York: Waxmann, 2016.

Kramer, Rita. Maria Montessori. NY: G.P.Putnam, 1976.

Kymlicka, Will. "Education for Citizenship." In Education in Morality, J. Mark Halstead and Terence H. McLaughlin, ed. London and New York: Routledge, 1999.

Lebar, Lois E. Education that is Christian. Colorado Springs, Colorado: Chariot Victor Publishing, 1995.

Lewis, Charlton T., ed. An Elementary Latin Dictionary, "Duco". Oxford; Oxford University Press, 1989 [1891].

Lines, Timothy Arthur. Functional mages of the Religious Educator. Birmingham, Alabama; Religious Education Press, 1992.

Lipkin, Robert Justin. "Pragmatism, Cultural Criticism, and the Idea of the Postmodern University." In An Ethical Education: Community and Morality in the Multicultural University, M.N.S. Sellers, ed. Oxford, UK: Berg Publishers, 1994.

Louw, Daniël J. "Xenophobia and social prejudice through the lens of Calvin: From 'iron philosophy' to homo sympatheticus in a practical theology of home within the global dilemma of displayed refugees." In Reformed Theology Today: Practical-theological and Ethical Perspectives, Sarel P. van der Walt and Nico Vorster, eds. Cape Town, South Africa: AOSIS, 2017.

Luntley, Michael. "Postmodernism and the Education of Character." In Education in Morality, J. Mark Halstead and Terence H. McLaughlin, ed. London and New York: Routledge, 1999.

McBride, Alfred A. and O. Praem. Creative Teaching in Christian Education. Boston, Massachusetts: Allyn and Becon Inc., 1978.

Melchert, Charles. "What is Religious Education?" In Critical Perspectives on Christian Education, Jeff Astley and Leslie J. Francis, eds. Melksham, Wiltshire: The Cromwell Press, 1994.

Miedema, Siebren. "Contexts, Debates and Perspectives of Religion in Education in Europe." In Religion and Education in Europe: Developments, Contexts and Debates, Robert Jackson, Siebren Miedema, Wolfram Weisse, Jean-Paul Willaime, eds. Vol. 3, Series Religious Diversity and Education in Europe. Münster, Waxmann, 2007.

Miedema, Siebren. "The End of Pedagogy? A Plea for Concrete Utopian Acting and Thinking." In Postmodernism and Education, P. Higgs, S. Miedema, J.L. van der Walt, and G. Zecha, 
eds. Conference readings, faculty of education, Potchefstroomse Universiteit vir Christelike Hoër Onderwys, September 1997.

Miller, Randolph Crump. "Religious Education in Europe." Religious Education, 55:2 (1960: Jan/Dec.): 141-143.

Moran, Gabriel. "Religious Education and International Understanding." In Education, Religion, and Society: Essays in Honour of John M. Hull, Dennis Bates, Gloria Durka, and Friederich Schweitzer, eds. Series Routledge Research in Education. London and New York; Routledge, Taylor \& Francis Group, 2006.

Munnik, R.P.H. Course notes/ discussions. Course U 40063 Christianity in Dialogue with the Modern Arts, Semester II, 2010 - 2011, Tilburg School of Theology, Tilburg University.

O'Brien, Peter. The Muslim Question in Europe: Political Controversies and Public Philosophies. Philadelphia, Rome, Tokyo: Temple University Press, 2016.

Parrinder, Geaffrey. World Religions: From Ancient History to the Present. New York, New York: Facts on Time Publications, 1983.

Peterson, Michael L. "Philosophy of Education: Issues and Options." In Contours of Christian Philosophy, Stephen C. Evans, ed. Downers Grove, Illinois; InterVarsity Press, 1986.

Pring, Richard. Philosophy of Education: Aims, Theory, Common Sense, and Research. London, New York: Continuum, 2004.

Proshak, Vitaliy V. A Philosophy of Religious Education in an Pluralist Society: Christian Evangelical Education in Ukraine Since 1991. MET thesis, Tyndale Theological Seminary, The Netherlands, February 2007, 23.

Proshak, Vitaliy V. "Models of Religious Education in Public Secondary Schools within European Research Context: The examples of France, Russia and The Netherlands." Theological Reflections, No. 11, 2010: 115-134.

Van Rensburg, Johannes Janse. "An Assessment of the Theology of Religion." In Perspectives of Theology of Religions, Jaco Beyers, eds. Series Teologiese Studies, Supplementun 12. Cape Town, South Africa: AOSIS, 2017.

RISU. U 2012 Rotsi Ugortshina Pochne Zhuty za Novoju Konstitutsieju, Zasnovanoju na Christianskih Tsinnostiah [In 2012 Hungary will Start to Live According to the New Constitution, Which is Based on the Christian Values], 27-03-2011, <www.risu.org.ua> (July 1, 2011).

Rodger, Alex. "Moral, Spiritual, Religious - Are They Synonymous?" In Spiritual and Religious Education, vol. V, Education, Culture, and Values, Mal Leicester, Celia Modgil, and Sohan Modgil, eds. London, UK: Falmer Press, 2000.

Rorty, Amelie Oksenberg. "Morality as an Educational Institution." In Education in Morality, Mark J. Halstead and Terence H. McLaugblin, eds. London and New York: Routledge, 1999.

Ross, Glen. "Metaphysical Skepticism and the Teaching of Philosophy." In Knowledge, Teaching, and Wisdom, Keith Lehrer, B. Jeannie Lum etc., eds. Philosophical Studies Series 67. Dordrecht, The Netherlands: Kluwer Academic Publishers, 1996. 
Sealey, John. Religious Education: Philosophical Perspectives. London, UK: George Allen and Unwin Ltd., 1985.

Schreiner, Peter. "Relihioznoe Obrazovanie v Evropejskom Kontekste [Religious Education in European Context]." In Religious Education in Europe: Situatio and current trends in schools, Elza Kuyk, Roger Jensen, David Lankshear, Elisabeth Löh Manna, and Peter Schreiner, eds., trans., Aleksandr Judin. Kyiv: Duh i Litera, 2013.

Smart, Ninian. "Religion." In A New Dictionary of Christian Theology, Alan Richardson and John Bowden, eds. London, Great Britain: SCM Press LTD, 1983.

Spinner-Halev, Jeff. Surviving Diversity: Religion and Democratic Citizenship. Baltimore, Maryland: The Johns Hopkins University Press, 2000.

Sprod, Tim. Philosophical Discussion in Moral Education: The Community of Ethical Inquiry. London and New York: Routledge, 2001.

Tett, Lyn. "Education and Community Health: Identity, Social Justice, and Lifestyle Issues in Communities." In Social Justice, Education, and Identity, Carol Vincent, ed. London and New York: RoutledgeFalmer, 2003.

Weisse, Wolfram. "Analysis of the Teacher's Responses to Religious Diversity in the Course of the REDCo Project - A Foreword." In Teachers Responding to Religious Diversity in Europe, Anna van der Want, Cok Bakker, Ina ter Avest, Judith Everington, eds. Vol. 8, Series Religious Diversity and Education in Europe. Münster, Waxmann, 2009.

Wilhout, Jim. Christian Education: The Search for Meaning, 2 ed. Grand Rapids, Michigan: Baker Book House, 1991.

Willaime, Jean-Paul. "Different Models for Religion and Education in Europe." In Religion and Education in Europe: Develpments, Context, and Debates, Robert Jackson, Siebren Miedema, Wolfram Weisse, Jean-Paul Willaime, eds. Series Religious Diversity and Education in Europe, Cok Bakker, Hans-Günter Heimbrock, Robert Jackson, Geir Skeie Wolfram Weisse, eds. Vol 3. Münster, New York; München, Berlin: Waxman, 2007.

Williams, Melissa S. "Citizenship as Identity, Citizenship as Shared Fate, and the Function of Multicultural Education." In Citizenship and Education in Liberal-Democratic Societies: Teaching for Cosmopolitan Values and Collective Identities, Kevin McDonough and Walter Feinberg, eds. New York, New York: Oxford University Press Inc., 2003.

Winch, Christopher. The Philosophy of Human Learning. London and New York: Routledge, 1998.

Wringe, Colin. Moral Education: Beyond the Teaching of Right and Wrong. Vol. 14, Series Philosophy and Education. Netherlands, Springer, 2006.

Van der Zwaan, Bert. Higher Education in 2040: A Global Approach. Amsterdam, The Netherlands: Amsterdam University Press, 2017. 